\title{
Going to the Polls or Feeding Children? An Empirical Investigation of Voter Turnout among Turkish Women with Children at Home
}

\author{
Deniz Güvercin* \\ Arel University
}

\begin{abstract}
This study is based on a data set published in the 2013 Turkey Demographic and Health Survey. The ordered logit econometric model is applied to examine the effects of the fertility preferences of women on their electoral participation. The results indicate that the number of children a woman has is negatively related to her electoral participation. The results also show that compared with women who had an additional child under six years and women who had an additional child between nine and thirteen years, women who had an additional child between six and nine years were less likely to vote. The estimation results indicate that married, educated, and high-income women are more likely to vote. These results also show that married women are more likely to vote when their income level increases. The estimation results also indicate that higher wealth status and educational attainment increase the electoral participation of women who have at least one child who is six years or younger. Moreover, the results indicate that the electoral participation of older women having a child at six years or younger is lower. Key Words: Voter Turnout, Number of Children, Ordered Logit Model, TDHS 2013.
\end{abstract}

\section{Seçim Sandığı mı Çocukların Yemeği mi? Türk Kadınlarının Seçimlere Katılımı Üzerine Uygulamalı Analiz}

\begin{abstract}
Özet
Bu çalışma 2013 yılı Türkiye Demografik ve Sağlık Anketi verileri kullanılarak yapılmıştır. Sıralı lojistik regresyon modeli kadınların doğurganlık tercihlerinin, seçimlere katılımları üzerine etkilerini incelemek için kullanılmıştır. Çalışma sonuçları; kadınların sahip olduğu çocuk sayısı ile seçimlere katılımları arasında negatif bir ilişki olduğunu göstermektedir. Çalışma; altı ve dokuz yaş arası ilave bir çocuğu daha olan kadınların altı yaş altı yada dokuz ve on üç yaş arası ilave bir çocuğu daha olan kadınlara göre daha düşük olasılıkla oy kullandığını göstermiştir. Tahmin sonuçları; evli, yüksek gelirli ya da eğitimli kadınların oy kullanmalarının daha olası olduğunu göstermiştir. Sonuçlar; evli kadınların gelir durumları arttıkça oy kullanmalarının daha yüksek olasılıklı olduğunu göstermiştir. Tahmin sonuçları; altı yaş altı en az bir çocuğu olan kadınların eğitim düzeyleri ve gelir düzeyleri arttıkça oy kullanma olasılıklarının arttığını göstermektedir. Bunlara ilaveten, çalışma sonuçları; daha yüksek yaşlarda altı yaş altı en az bir çocuğu olan kadınların daha düşük yaşlarda altı yaş altı en az bir çocuğu olan kadınlara göre daha az olasılıkla oy kullandıklarını göstermiştir. Anahtar Kelimeler: Seçimlere Katılım, Çocuk Sayısı, Sıralı Lojistik Modeli, TDSA 2013
\end{abstract}

\footnotetext{
* Assistant Prof. Dr. Deniz Güvercin, Istanbul Arel University, Department of International Trade and Finance, Türkoba Mahallesi Erguvan Sokak No:26 / K 34537 Tepekent -Büyükçekmece,İstanbul-Türkiye, E-mail: denizguvercin@ arel.edu.tr
} 


\section{Introduction}

Although women constitute a significant portion of the world population, their electoral participation level is low (Kostelka et al., 2018; Inglehart and Norris, 2003). The literature on gender gaps in political behavior focuses on cultural explanations (Inglehart and Norris, 2003), socioeconomic characteristics (Sapiro, 1981; Burns et al., 2001), group membership (Putnam, 1993), and political context (Burns et al. 2001; Kittilson and Schwindt-Bayer, 2012). Previous studies based on socioeconomic characteristics focus on marital status, age, education, and wealth status to explain the low participation of women in the electoral process. However, very few studies have focused on the relationship between fertility and voter turnout. This study aims to contribute to the relevant literature by examining empirical evidence of the relation between the fertility preferences of women and their electoral participation.

In the voter turnout literature, numerous studies have explained the variations in voter turnout across countries and time. Electoral laws and regulations (Jackman, 1987), education (Tenn, 2007), wealth level (Wolfinger and Rosenstone, 1980; Smets and Van Ham, 2013), age (Blais, 2000), marital status (Wolfinger and Wolfinger, 2008; Stoker and Jennings, 1995), macroeconomic development (Aguilar and Pacek, 2000; Pacek and Radcliff, 1995), and urbanrural disparity (Thananithchot, 2012) have been reported as factors that affect variations in voter turnout.

In the expected utility model of voter turnout proposed by Downs (1957), voting occurs if the voter has an expected utility that is higher than the expected cost of voting. According to the model, if $R=B * P+D-C>0$, the net expected utility (R) is greater than zero, and voting occurs ${ }^{1}$. Therefore, as a rational decision maker, the voter compares the cost and benefits of voting. If the cost of voting is greater than its benefits, then the voter chooses not to vote. Because the probability of being the pivotal voter is very low (Gelman et al., 1998; Mullingan and Hunter, 2003), the model predicts that the voter would not participate in elections, which contradicts the high voter turnout rates observed in real life, leading to the phenomenon known as the paradox of voting.

Several theories of voter turnout have been developed that focus on those aspects of Downs' (1957) model that fail to address electoral participation in real life. Fowler and Kam (2007) criticize Downs' model of electoral participation by showing that voter turnout is not based solely on self-interest but on altruism and social identification. Morton (1987) and Uhlaner (1989) emphasize the role of the interests of the groups with which voters are affiliated in their electoral participation. The minimax regret theory (Ferejohn and Fiorina, 1974) focuses on the regret incurred by voters in the cases where elections result in a tie or one vote short of a tie. Degan and Merlo (2004) argued that uninformed voters are more uncertain about the "right" candidate, so they abstain from voting because of the high probability of choosing the "wrong" candidate. Because of the greater likelihood that uninformed voters would experience regret about their choice, there would be a higher turnout of informed voters which would lead to biased political outcomes if the informed voters are from a particular socio-economic class.

Other studies focus on genetic factors to explain variations in voter turnout (Fowler et al. 2008; Fowler and Dawes, 2008) by showing associations between certain genes (i.e., polymorphism of the 5HTT gene) and voter turnout. Sociological studies on voter turnout focus on voting

\footnotetext{
${ }^{1} \mathrm{P}$ is the subjective probability of being the pivotal voter; $\mathrm{B}$ is the benefits accrued after the party is elected; $\mathrm{C}$ is the costs of voting, such as money and time; and $\mathrm{D}$ is the psychological benefits.
} 
history and its effects on future voting behavior by associating parental resources and political involvement with initial voting behavior (Plutzer, 2002; Gerber et al., 2003). Resource mobilization literature argues that an individual's wealth level is closely related to voter turnout (Brady et al. 1995; Lijphart, 2012; Smets et al. 2013) and that the poor vote less often than the rich. There are studies showing that the poor become more prone to vote if left wing parties have a high share of the vote (Gallego, 2009; Gimpel et al. 2007).

Studies on the effects of psychological factors on voter turnout show that gratitude expressions (e.g., "thank you") or feelings of shame or pride due to the disclosure of voting abstention or participation (Gerber et al. 2008; Gerber et al. 2010) positively affect voter turnout. Granber and Holmberg (1992) and Person (2014) show that electoral participation behavior changes if a person participates in a survey on electoral participation, implying that the subject's political behavior might change if the subject's behavior were observable. Nickerson and Rogers (2010) show that the formation of a voting plan enabled by interventions increases electoral participation. Gerber and Rogers (2009) show that people who vote irregularly are more motivated than regular voters in the presence of high or low voter turnout in the general population.

Riker and Ordeshook (1968) argued that people vote to express themselves or to ensure that democracy will continue (Downs, 1957). According to the expressive voting theory, voters participate in elections to perform voting activities rather than gain benefits from elections (Schuessler, 2000). The ethical voting literature (Harsanyi, 1977; Andreoni, 1989; Fowler, 2006; Jankowski, 2007) focuses on altruistic motives in electoral participation. Some scholars have focused on the motive of civic duty in voting (Blais, 2000). According to Blais (2000), people vote to help others who would benefit from the election results.

Additionally, according to both the expressive voting theory and Blais's (2000) civic duty approach, a mother might vote because she feels responsible for ensuring the survival of democracy for her children (Downs, 1957). Moreover, a mother might sacrifice resources, such as time (waiting in lines at the polling station) and money (costs of commuting or gathering information about candidates), to participate in elections and to choose the "right" candidate for the future of her children.

Institutional features, such as compulsory voting, registering to vote before elections, the availability of postal voting, and the accessibility of the ballot box have been shown to affect voting patterns (Franklin, 1996; Norris, 2003; Gimpel and Schucknecht, 2003; Blais, 2006), particularly those of women with children, who have less time for other activities. Another institutional factor is campaign expenditures (Cancela and Geys, 2016) that affect the political participation of women with children by increasing the probability of obtaining information about candidates and political issues. On election day, the availability of caregiving provided by the government for children or elderly people increases women's propensity for voting, particularly in societies where women specialize in caregiving. Additionally, household income positively affects the voter turnout of women who can afford to pay for caregiving services on election day.

Only a few studies examine the effect of fertility on mothers' electoral participation. Arnold (2013) found that a mother's voter turnout decreased according to the number of young children and the length of voting lines. Wolfinger and Wolfinger (2008) found that parents with children were less likely to vote. However, Plutzer (2002) showed that having children had no effect on voter turnout. 
This study aims to fill the gap in the literature by providing evidence of the effect of the number of children on the electoral participation level of their mothers. The study is based on the data set published in the 2013 Turkish Demography and Health Survey (TDHS). The number of previous studies on the voting behavior of the Turkish voter is limited. These studies (Akarca and Tansel, 2006, 2007; Çarkoglu, 1997; Baslevent et al., 2005; Güvercin, 2017) were focused mainly on the social and economic determinants of party selection by Turkish voters.

Turkey has one of the largest gender gaps in employment in the world. Following the import substitution industrialization period of 1950-1980, in the period of export-led growth industrialization, women increased their participation in the non-agricultural economic labor force. However, the increase was small (Illkkaracan 2012). In the traditional division of labor, the male is the head of the household and participates in the labor market, whereas female family members are responsible for home production, which constrains women's participation in the labor market. Furthermore, in addition to the effects of gender-based social norms on the labor supply, gender discrimination by employers leads to an insufficient demand for female workers in the presence of a large supply of unskilled and non-unionized male workers (Buğra and Yakut-Çakar, 2010). Additionally, the export industry (e.g., garment manufacturing), which attracts a substantial number of female laborers, has been criticized for reproducing gender inequalities and gender-based social norms (Dedeoğlu, 2010). Because the male breadwinner model induces the lower participation of women in the economy and politics (Iversen and Rosenbluth, 2008), mothers tend to be uninterested in and uninformed about the characteristics of candidates and the consequences of elections, which affects the turnout of women voters.

In Turkey, the female labor force participation rate has been around 30 percent and is below the OECD average (Atasoy, 2017). One reason for women's low participation in the labor market is that the Turkish state does not provide or subsidize childcare or preschool education (İlkkaracan, 2012). According to a survey conducted by the Turkish Statistics Institute in 2006, in 91 percent of urban households with children aged 0-5 years, the mother provides the necessary childcare. Moreover, the regulations imposed on private early childhood education and care services (ECEC) by the Turkish state make access to these services by the poor even more difficult (Aran et al., 2016). Therefore, the lack of public ECEC services and an inability to afford their high-cost private equivalents negatively affect women's participation in the labor force. Moreover, their low participation in the labor force decreases women's awareness and knowledge of current economic and political issues, thereby affecting the magnitude and quality of women's political participation in Turkey.

This article is structured as follows. The next section provides information about the data set and descriptive statistics. The third section discusses our econometric methodology and model and describes the estimation results. The fourth section provides a discussion and conclusion.

\section{Data}

The data used in the study was gathered from the 2013 Turkish Demography and Health Survey (TDHS) conducted by Hacettepe University in Turkey. The TDHS 2013 was a nationally representative survey of 11,794 households and 9,746 "ever married" and "never married" women of reproductive age (15-49 years). The TDHS 2013 includes data on the socioeconomic well-being, demographics, and health status of the surveyed women, including information about their electoral behavior. The survey data used in the present study included information 
about the electoral behavior, number of children, educational attainment, age, marital status, wealth level ${ }^{2}$, geographical region of residence (12 NUTS-1 level regions), rural/urban status, birth province, education levels of parents, and language spoken by the respondent in the interview.

Table 1 provides the descriptive statistics of most of the variables used in the study. Because the TDHS 2013 also includes information about women who are not eligible to vote some irrelevant data was excluded from the sample for the purpose of this study.

Table 1. Descriptive Statistics

\begin{tabular}{|c|c|c|c|c|c|}
\hline Variable & $\begin{array}{l}\text { Number of } \\
\text { Observations }\end{array}$ & Mean & $\begin{array}{l}\text { Standard } \\
\text { Deviation }\end{array}$ & Minimum & Maximum \\
\hline Vote in Election & 8,375 & 1.8 & .49 & 0 & 2 \\
\hline Age & 8,375 & 33.34 & 8.7 & 15 & 49 \\
\hline Age Square & 8,375 & 1187.5 & 585.2 & 225 & 2401 \\
\hline Years of Education & 8,372 & 7.06 & 4.4 & 0 & 21 \\
\hline $\begin{array}{l}\text { Wealth- Poor Wealth } \\
\text { Level }\end{array}$ & 3,586 & 0 & 0 & 0 & 0 \\
\hline $\begin{array}{l}\text { Wealth -Middle Wealth } \\
\text { Level }\end{array}$ & 1,720 & 1 & 0 & 1 & 1 \\
\hline Wealth-Rich Wealth Level & 3,069 & 2 & 0 & 2 & 2 \\
\hline Marital Status-Married & 6,640 & 1 & 0 & 1 & 1 \\
\hline $\begin{array}{l}\text { Number of Living } \\
\text { Children }\end{array}$ & 8,375 & 2 & 1.7 & 0 & 12 \\
\hline $\begin{array}{l}\text { Number of Living } \\
\text { Children Under Age } 6\end{array}$ & 8,375 & .58 & .82 & 0 & 5 \\
\hline $\begin{array}{l}\text { Number of Living } \\
\text { Children Between Age 6-9 }\end{array}$ & 8,375 & .24 & .49 & 0 & 4 \\
\hline $\begin{array}{l}\text { Number of Living } \\
\text { Children Between Age 9- } \\
13\end{array}$ & 8,375 & .34 & .62 & 0 & 4 \\
\hline Type of Residence -Rural & 2,207 & 1 & 0 & 1 & 1 \\
\hline Type of Residence -Urban & 6,168 & 2 & 0 & 2 & 2 \\
\hline
\end{tabular}

\section{Econometric Models and Estimation Results}

The dependent variable is the voting behavior of the women who participated in the 2013 Turkish Demography and Health Survey. It indicates whether the respondent does not vote, votes regularly, or votes irregularly. The number of children of the respondent women is the key variable, and $X$ is the set of control variables referred to in the models.

In this study, the ordered logit model (OLM) is applied to estimate the effect of the number of children on voting behavior. The OLM is implemented when the dependent variable is ordinal

\footnotetext{
2 The Wealth index is constructed using household asset data including ownership of a number of possessions ranging from a television to a car, dwelling characteristics, such as source of drinking water, type of flooring material (TDHS, 2013). 
and can be expressed in categories, as in this study. The OLM is used to establish the association between explanatory variables and the set of probabilities of the categories (Grilli and Rampichini, 2014).

The ordinal dependent variable, Vote, has three ordered categories, and it is expressed by two equations. The three categories are not participating in elections (Vote $=0$ ), participating irregularly (Vote $=1)$, and participating regularly (Vote $=2$ ). The cumulative probabilities, $g_{c i}=$ Prob $\left(\right.$ Vote $_{\mathrm{i}} \leq$ Vote $\left._{\mathrm{c}} \mid X_{i}\right), c=1,2$, and 3 are related to the explanatory variables through the logit function. The parameter $\alpha_{c}$, thresholds, is in increasing order $\left(\alpha_{1}<\alpha_{2}<\alpha_{3}\right)$. The cumulative model is the following:

$$
\left(\frac{g_{c i}}{1-g_{c i}}\right)=\alpha_{c}-\left(\beta_{0}+\beta_{1} \text { Number of Children } i+\Theta^{\prime} X_{i}\right)
$$

The cumulative model of an ordinal dependent variable can be represented by a linear regression model with a set of thresholds $\alpha_{c}^{*}$. In the model, the ordinal dependent variable with $\mathrm{C}$ categories - Vote with three categories - can be expressed as a continuous variable with C-1 categories, such that Vote $_{i}=$ Vote $_{c}$ if and only if $\alpha_{c-1}^{*} \leq$ Vote $_{i}^{*} \leq \alpha_{c}^{*}$ where Vote ${ }^{*}$ is the continuous dependent variable. The error, $\varepsilon_{i}$, has a zero mean and constant variance. The logistic function in equation (1) is the inverse of the distribution function of the error, $\varepsilon_{i}$ (Grilli and Rampichini, 2014).

The linear regression models are the following:

Vote $_{i}^{*}=\beta_{0}^{*}+\beta_{1}^{*}$ Number of Children $+\Theta^{* \prime} X_{i}+\varepsilon_{i}$

Vote $_{i}^{*}=\varphi_{0}^{*}+\varphi_{1}^{*}$ Number of Living Children Under Age $6+\gamma^{*} X_{i}+e_{i}$

Vote $_{i}^{*}=\mu_{0}^{*}+\mu_{1}^{*}$ Number of Living Children Between Age 6-9+ $\omega^{* \prime} X_{i}+v_{i}$

Vote $_{i}^{*}=\chi_{0}^{*}+\chi_{1}^{*}$ Number of Living Children Between Age 9-13+ $\delta^{\star \prime} X_{i}+u_{i}$

The models based on these equations are used to unravel the relation between the fertility rate of women and their voter turnout. Therefore, the coefficient estimates indicate that the fertility choice of women affects their electoral participation behavior.

Table 2. Ordered Logit Regression Estimation Results

\begin{tabular}{l|l|l|l|l|l}
\hline Variables & Model 1 & Model 2 & Model 3 & Model 4 & Model 5 \\
\hline $\begin{array}{l}\text { Number of Living } \\
\text { Children }\end{array}$ & $\begin{array}{l}-.1^{*} \\
(.05)\end{array}$ & & & & \\
\hline $\begin{array}{l}\text { Number of Living } \\
\text { Children Under Age 6 }\end{array}$ & & $-.18^{* *}$ & & & \\
\hline $\begin{array}{l}\text { Number of Living } \\
\text { Children Between Age 6- } \\
9\end{array}$ & & $(.09)$ & & & \\
\hline $\begin{array}{l}\text { Number of Living } \\
\text { Children Between Age 9- }\end{array}$ & & & $-.44 \quad * * *$ & & $(.08)$ \\
13 & & & & & \\
\hline Age & & & & & \\
\hline
\end{tabular}




\begin{tabular}{|c|c|c|c|c|c|}
\hline Age Square & $\begin{array}{ll}.01 * * * \quad(.001) \\
\end{array}$ & $\begin{array}{l}-.01 * * * \\
(.0017)\end{array}$ & $\begin{array}{l}-.01 * * * \\
(.0017)\end{array}$ & $-.01 * * *(.001)$ & $\begin{array}{l}-.011 * * * \\
(.0018)\end{array}$ \\
\hline Years of Education & $\begin{array}{l}.07 * * * \\
(.02)\end{array}$ & $\begin{array}{l}.07 * * * \\
(.02)\end{array}$ & $\begin{array}{ll}.07 & * * * \\
(.019) & \end{array}$ & $\begin{array}{l}.076^{* * * *} \\
(.02)\end{array}$ & $\begin{array}{l}.06 * * * \\
(.02)\end{array}$ \\
\hline Married & $\begin{array}{l}.57 * * * \\
(.14)\end{array}$ & $\begin{array}{l}.64 * * * \\
(.14)\end{array}$ & $\begin{array}{l}.5 * * * \\
(.13)\end{array}$ & $\begin{array}{l}.47 * * * \\
(.13)\end{array}$ & $\begin{array}{l}.66^{* * *} \\
(.14)\end{array}$ \\
\hline $\begin{array}{l}\text { Wealth -Middle Wealth } \\
\text { Level }\end{array}$ & $(.17)$ & $\begin{array}{l}.28 \\
(.18)\end{array}$ & $\begin{array}{l}.29^{*} \\
(.18)\end{array}$ & $\begin{array}{l}.29 * \\
(.18)\end{array}$ & $\begin{array}{l}.27 \\
(.18)\end{array}$ \\
\hline $\begin{array}{l}\text { Wealth-Rich Wealth } \\
\text { Level }\end{array}$ & $\begin{array}{l}.12 \\
(.19)\end{array}$ & $\begin{array}{l}.11 \\
(.19)\end{array}$ & $\begin{array}{l}.13 \\
(.19)\end{array}$ & $.13 \quad(.19)$ & $\begin{array}{l}.1 \\
(.19)\end{array}$ \\
\hline Type of Residence -Urban & $(.13)$ & $\begin{array}{l}.01 \\
(.13)\end{array}$ & $\begin{array}{l}.0007 \\
(.13)\end{array}$ & $\begin{array}{l}.003 \\
(.13)\end{array}$ & $\begin{array}{l}.004 \\
(.13)\end{array}$ \\
\hline Region- Istanbul & $\begin{array}{l}-.64 * * \\
(.3)\end{array}$ & $\begin{array}{l}-.62 * * \\
(.3)\end{array}$ & $\begin{array}{l}-.62 * * \\
(.31)\end{array}$ & $\begin{array}{l}-.63 * * \\
(.3)\end{array}$ & $\begin{array}{l}-.64 * * \\
(.31)\end{array}$ \\
\hline Region- West Marmara & $-1.03 * * * \quad(.4)$ & $\begin{array}{l}-.98 \\
(.39)\end{array}$ & $\begin{array}{l}-1.002 * * * \\
(.39)\end{array}$ & $\begin{array}{l}-1.02 * * * \\
(.4)\end{array}$ & $\begin{array}{l}-1.04 * * * \\
(.39)\end{array}$ \\
\hline Region- Aegean & \begin{tabular}{|l|}
.07 \\
$(.54)$
\end{tabular} & $\begin{array}{l}.1 \\
(.54)\end{array}$ & $\begin{array}{l}.08 \\
(.54)\end{array}$ & $\begin{array}{l}.09 \\
(.53)\end{array}$ & $\begin{array}{l}.033 \\
(.55)\end{array}$ \\
\hline Region- East Marmara & $(.34)$ & $\begin{array}{l}.37 \\
(.33)\end{array}$ & $\begin{array}{l}.36 \\
(.33)\end{array}$ & $\begin{array}{l}.36 \\
(.33)\end{array}$ & $\begin{array}{l}.34 \\
(.41)\end{array}$ \\
\hline Region- West Anatolia & \begin{tabular}{|l|}
-.26 \\
$(.34)$
\end{tabular} & $\begin{array}{l}-.24 \\
(.34)\end{array}$ & $\begin{array}{l}-.25 \\
(.34)\end{array}$ & $\begin{array}{l}-.26 \\
(.34)\end{array}$ & $\begin{array}{l}-.26 \\
(.35)\end{array}$ \\
\hline Region- Mediterranean & .33 & $\begin{array}{l}.33 \\
(.4)\end{array}$ & $\begin{array}{l}.34 \\
(.4)\end{array}$ & $\begin{array}{l}.33 \\
(.4)\end{array}$ & $\begin{array}{l}.34 \\
(.41)\end{array}$ \\
\hline Region- West Black Sea & \begin{tabular}{|l|}
-.46 \\
$(.3)$ \\
\end{tabular} & $\begin{array}{l}-.44 \\
(.31)\end{array}$ & $\begin{array}{l}-.42 \\
(.31)\end{array}$ & $-.44 \quad(.31)$ & $\begin{array}{l}-.44 \\
(.31)\end{array}$ \\
\hline Region- East Black Sea & \begin{tabular}{|l}
$.99 * * *$ \\
$(.38)$ \\
\end{tabular} & $\begin{array}{l}.99 * * * \\
(.38)\end{array}$ & $\begin{array}{l}.99 * * * \\
(.39)\end{array}$ & $\begin{array}{l}.98 * * * \\
(.39)\end{array}$ & $\begin{array}{l}.99 * * * \\
(.39)\end{array}$ \\
\hline $\begin{array}{ll}\text { Region- } & \text { Northeast } \\
\text { Anatolia } & \end{array}$ & $\begin{array}{l}.4 \\
(.46)\end{array}$ & $\begin{array}{l}.43 \\
(.46)\end{array}$ & $\begin{array}{l}.39 \\
(.46)\end{array}$ & $.4 \quad(.45)$ & $\begin{array}{l}.4 \\
(.47)\end{array}$ \\
\hline $\begin{array}{ll}\text { Region-Central East } \\
\text { Anatolia }\end{array}$ & $(.42)$ & $\begin{array}{l}-.6 \\
(.42)\end{array}$ & $\begin{array}{l}-.56 \\
(.42)\end{array}$ & $\begin{array}{l}-.6 \\
(.42)\end{array}$ & $\begin{array}{l}.58 \\
(.43)\end{array}$ \\
\hline $\begin{array}{l}\text { Region-Southeast } \\
\text { Anatolia }\end{array}$ & -.35 & $\begin{array}{l}-.35 \\
(.4)\end{array}$ & $\begin{array}{l}-.33 \\
(.41)\end{array}$ & $\begin{array}{l}-.39 \\
(.41)\end{array}$ & $\begin{array}{l}-.31 \\
(.42)\end{array}$ \\
\hline Number of Observation & 8,372 & 8,372 & 8,372 & 8,372 & 8,372 \\
\hline Chi2 & \begin{tabular}{|l|}
7907.8 \\
\end{tabular} & 8053.5 & 6832.2 & 7160.3 & 7191.8 \\
\hline Prob> Chi2 & 0.0000 & 0.0000 & 0.0000 & 0.0000 & 0.0000 \\
\hline Pseudo R2 & .27 & .29 & .29 & .29 & .3 \\
\hline
\end{tabular}

Notes: * significant at 1 percent, $* *$ significant at 5 percent, and $* * *$ significant at 10 percent. Clustered standard errors are reported in paranthesis where the birth year is used as the cluster unit.

The control variables included in all models are displayed in Table 2: age of the respondent; square of the age of the respondent; wealth status; years of education; type of residence; marital status; birth province; the education level of the mother and father; and the language used by the respondent in the interview. We claim that the number of children of different ages have 
various effects on the voter turnout of their mothers. Because children of certain ages require greater parental control, attendance at elections that requires a significant amount of time is difficult for women with young children. Compared with children under 6 years, less parental care is required for older children, such as children aged 6-9 years and 9-13 years, who have higher bargaining power relative to small age children and the use of parents' available time. Therefore, we provide evidence on the effects of different age groups on the voting behavior of women.

The results displayed in Table 2 show that the total number of children and the number of children in different age groups (under 6 years, 6-9 years, and 9-13 years) decreased the electoral participation of their mothers. These results imply that education level, age, marital status, and wealth level (middle income or low income) increase the electoral participation of women with children. The negative sign in the age square variable indicates that at older ages, electoral participation is lower. Additionally, the regional dummy variables indicate that living in Istanbul, West Marmara compared with the Central Anatolia (the reference region) decreased electoral participation whereas living in the East Black Sea region compared with Central Anatolia increased electoral participation. High commuting costs due to traffic congestion, exhaustive working hours, city life, and low family quality time resulting from high urbanization in Istanbul and Western Marmara mostly account for the low electoral participation in these regions. Electoral participation in the East Black Sea region, which is conservative-nationalist, would be explained by the current incumbent party's regional ties.

Table 3. Ordered Logit Regression Estimation Results

\begin{tabular}{|c|c|c|c|}
\hline Variables & Outcome $=N o$ & Outcome $=$ Irregular & Outcome $=$ Regula \\
\hline $\begin{array}{l}\text { Number of Living Children } \\
\text { (Model 1) }\end{array}$ & $\begin{array}{l}.0045 * \\
(.0024)\end{array}$ & $\begin{array}{l}.0006 * * \\
(.0003)\end{array}$ & $\begin{array}{l}-.005 * * \\
(.002)\end{array}$ \\
\hline $\begin{array}{l}\text { Number of Living Children Under } \\
\text { The Age of } 6 \text { (Model 2) }\end{array}$ & $\begin{array}{l}.008 * * \\
(.0038)\end{array}$ & $\begin{array}{l}.001 * * \\
(.0005)\end{array}$ & $\begin{array}{l}-.009 * * \\
(.004)\end{array}$ \\
\hline $\begin{array}{l}\text { Number of Living Children } \\
\text { Between Ages of 6-9 (Model 3) }\end{array}$ & $\begin{array}{l}.018 * * * \\
(.0057)\end{array}$ & $\begin{array}{l}.002 * * * \\
(.0006)\end{array}$ & $\begin{array}{l}-.02 * * * \\
(.006)\end{array}$ \\
\hline $\begin{array}{l}\text { Number of Living } \\
\text { Between Ages of 9-13 } \\
\text { (Model 4) }\end{array}$ & $\begin{array}{l}.01^{*} \\
(.006)\end{array}$ & $\begin{array}{l}.0013 * * \\
(.0007)\end{array}$ & $\begin{array}{l}-.012 * \\
(.006)\end{array}$ \\
\hline CONTROL VARIABLES & YES & YES & YES \\
\hline Number of Observation & 8,372 & 8,372 & 8,372 \\
\hline
\end{tabular}

As shown in Table 3, the predicted probabilities of voting under assigned categories were indicated by increases in the following explanatory variables: number of living children; number of living children under 6 years old; number of living children between 6-9 years old; number of living children between 9-13 years old. These results showed that if a woman had an additional child, the probability of not voting increased by .0045 ; the probability of voting irregularly increased by .0006; and the probability of voting regularly decreased by .005 . The results showed that if a woman had an additional child under the age of 6 years, the probability of not voting increased by .008; the probability of voting irregularly increased by .001; and the probability of voting regularly decreased by .009. The results showed that if a woman had an additional child between 6-9 years old, the probability of not voting increased by .018; the 
probability of voting irregularly increased by .002 ; and the probability of voting regularly decreased by .02. The results showed that if a woman had an additional child between 9-13 years old, the probability of not voting increased by .01; the probability of voting irregularly increased by .0013; and the probability of voting regularly decreased by .012 . These results indicate that having an additional child between the ages 6 and 9 years significantly decreases women's electoral participation.

Table 4. Ordered Logit Regression Estimation Results: Models with Interactions

\begin{tabular}{|c|c|c|c|c|}
\hline Variables & Model 1 & Model 2 & Model 3 & Model 4 \\
\hline Number of Living Children & $\begin{array}{l}.09 * \\
(.056) \\
\end{array}$ & & & \\
\hline $\begin{array}{l}\text { Number of Living Children } \\
\text { Under Age } 6\end{array}$ & & $\begin{array}{l}-.27 * * * \\
(.09)\end{array}$ & $\begin{array}{l}-.33 * * * \\
(.12)\end{array}$ & $\begin{array}{l}1.08 * * * \\
(.3)\end{array}$ \\
\hline $\begin{array}{l}\text { Number of Living Children } \\
\text { Between Age 6-9 }\end{array}$ & & $\begin{array}{l}-.37 * * * \\
(.13)\end{array}$ & $\begin{array}{l}-.36 * * * \\
(.12)\end{array}$ & $\begin{array}{l}-.3 * * * \\
(.1)\end{array}$ \\
\hline $\begin{array}{l}\text { Number of Living Children } \\
\text { Between Age 9-13 }\end{array}$ & & $-.17 \quad(.13)$ & $\begin{array}{l}-.16 \\
(.13)\end{array}$ & $\begin{array}{l}-.04 \\
(.13)\end{array}$ \\
\hline $\begin{array}{l}\text { Wealth* Married : Wealth - } \\
\text { Middle Wealth Level }\end{array}$ & $\begin{array}{l}.96 * * * \\
(.24)\end{array}$ & & . & \\
\hline $\begin{array}{ll}\text { Wealth* Married : } & \text { Wealth } \\
\text { Rich Wealth Level } & \end{array}$ & $\begin{array}{l}.24 \\
(.25)\end{array}$ & & & \\
\hline Wealth*Child6 & & $.27 * * * \quad(.1)$ & & \\
\hline Education Years*Child6 & & & $\begin{array}{l}.03 * * \\
(.015)\end{array}$ & \\
\hline Age*Child6 & & & & $\begin{array}{l}-.04 * * * \\
(.01)\end{array}$ \\
\hline CONTROL VARIABLES & YES & YES & YES & YES \\
\hline Number of Observation & 8,372 & 8,372 & 8,372 & 8,372 \\
\hline Chi2 & 17150 & 1097.9 & 7593.3 & 6725.6 \\
\hline Prob> Chi2 & 0.0000 & 0.0000 & 0.0000 & 0.0000 \\
\hline Pseudo R2 & .29 & .3 & .3 & .3 \\
\hline
\end{tabular}

In this study, interaction models were applied to explore the effects of several status variables, such as marital status, wealth status, and educational attainment, on voting behavior according to the number of children. Arnold (2013) found that low-income families had a lower likelihood of voting, whereas having an additional child did not affect the likelihood of electoral 
participation by high-income families. Wolfinger and Wolfinger (2008) showed that married couples with children were more likely to vote than separated adults with children.

In this study, the estimation results indicate that married women with middle incomes have higher participation rates in elections compared to with women with low incomes. Moreover, it could also be inferred that married women with middle incomes have higher voter turnout compared to single women with middle incomes. The estimation results indicate that an increase in wealth level increases the electoral participation of women having at least one child 6 years or younger, which increases the electoral participation of women having at least one child 6 years or younger. Moreover, the results indicate the lower electoral participation of older women with one child 6 years or younger.

Overall, these results indicate that wealth, education, and being married contribute positively to the electoral participation of mothers. Education and wealth level contribute positively to the voter turnout of mothers with a child 6 years or younger. Young children require constant attention and interest daily, and election day is not an exception. The results indicate that wealth level or being married enables mothers to vote. Furthermore, the results indicate that educated mothers with a child 6 years or younger are more motivated to vote compared to uneducated mothers having a child 6 years or younger.

\section{Discussion and Conclusion}

Very few studies in the voter turnout literature examine the effects of the fertility preferences of women on their electoral participation. Moreover, there are only a few studies on the voting behavior of the Turkish electorate. The study aimed to fill the gap in the literature by providing evidence for a causal relationship between the number of children and the voting behavior of Turkish mothers. The findings of this study contribute not only to the fields of electoral democracy and Turkish politics but also to the fields of demography and population economics.

The results of the econometric estimations indicate that education level, age, marital status (being married) and wealth level (middle income compared with low income) increase electoral participation. The negative sign in the square of age variable indicate that at older ages, electoral participation is lower. Additionally, the regional dummy variables indicate that living in Istanbul, West Marmara compared to living in the Central Anatolia (reference region) decreased electoral participation, whereas living in East Black Sea compared to living in Central Anatolia increased electoral participation.

Specifically, the results showed that if a woman had an additional child, the probability of not voting increased by .006; the probability of voting irregularly increased by .008; and the probability of voting regularly decreased by .006 . The results also showed that if a woman had an additional child under 6 years old, the probability of not voting increased by .01; the probability of voting irregularly increased by .0013; and the probability of voting regularly decreased by .011 . The results also showed that if a woman had an additional child from 6-9 years old, the probability of not voting increased by .02; the probability of voting irregularly increased by .002; and the probability of voting regularly decreased by .02 . Additionally, the results showed that if a woman had an additional child from 9-13 years old, the probability of not voting increased by .014; the probability of voting irregularly increased by .0018; and the probability of voting regularly decreased by .016. These results indicate that having an additional child between the ages of 6 and 9 years significantly decreases electoral participation by women. 
The estimation results show that married women with middle incomes have higher participation in elections compared with married women with low incomes. Additionally, the increase in wealth level increases the electoral participation of women having at least one child 6 years or younger. The results also showed that education increases the electoral participation of women having at least one child 6 years or younger. In addition, the results showed that electoral participation was lower in older women having a child 6 years or younger. These results indicate that wealth, education and being married contribute positively to the electoral participation of mothers with children. Education and wealth level contribute positively to the electoral participation of mothers having a child 6 years or younger, whereas the age of the respondent having a child 6 years or younger age decreases the probability of voter turnout.

These results support Arnold (2013) and Wolfinger and Wolfinger (2008) but contradict Plutzer's (2002) finding that there was no effect of children on voter turnout. The results of this study indicate that in Turkey, mothers contribute less to participatory politics, which decreases the pressure on political institutions to respond to the demands of women. Furthermore, "unequal turnout spells unequal political influence" (Lijphart, 1997, p. 1), which exacerbates gender-based inequalities. Because of the low voter turnout of Turkish women with children, information about their preferences in social welfare policies, such as caregiving, gender issues, and gender wage gap, are not expressed, which negatively affects their already low participation in the labor market.

The political participation of women, particularly mothers, could enable their economic empowerment (i.e., their access to decent jobs), which could increase their strength in civil society and in local women's organizations that promote gender equality and woman-friendly policies. Increasing women's participation might also induce political parties to nominate more female legislators, whose priorities may differ from those of male legislators (Bratton and Ray, 2002; Childs, 2004, Güvercin, 2019), and who might increase the pressure on both ruling and opposition parties to implement local and universal welfare policies, including free caregiving services and maternity leave.

It could be argued that the lack of public caregiving services in Turkey has had a negative impact on electoral participation because mothers are unable to vote, register to vote, or access information about political and economic issues. In this study, the significance of the relation between the dummy variable of children 6 years and younger and income level demonstrates that a wealthy mother who can access expensive caregiving services is more likely to vote.

The findings of this study also indicate that older mothers with a small child (6 years or younger) have lower rates of voter turnout because of either habit formation or intensive parenting, or both. This group of mothers could be assisted through designing electoral institutions, such as voting by mail, designing more flexible voting schedules, and by voting incentives such as using phone calls or reminder text messages to induce habitual (non-) voters to form a voting plan (Nickerson, 2006; Nickerson and Rogers, 2010; Dale and Strauss, 2009). Several studies in the literature have shown the significance of spousal interactions regarding politics (Zuckerman et al. 2007). Thus, policies could be developed to motivate husbands to encourage their wives to participate in elections.

Moreover, the cost of voting includes gaining access to information about party platforms and candidates. The results of this study indicate that the participation of mothers increases with their education level; indeed, schooling enhances the ability to analyze political developments. Therefore, campaigns such as canvassing door to door and increasing the media coverage of 
candidates would decrease the cost of obtaining information about politics, which might then increase the voter turnout of mothers with low levels of education.

The results of this study provide important information for policy makers and electoral institutions regarding low electoral participation. Policies aimed at free caregiving services, reminder text messages, door-to-door canvassing, and voting by mail could increase the participation of mothers, particularly those with many young children and low incomes. Furthermore, civil society, particularly women's organizations, should provide incentives for mothers so that their aggregated preferences for universal welfare state policies could be expressed through their full participation in the electoral process. 


\section{References}

Aguilar, E. E. and Pacek, A. C. (2000). Macroeconomic conditions, voter turnout, and the working-class/economically disadvantaged party vote in developing countries. Comparative Political Studies, 33(8), 995-1017.

Akarca, Ali and Aysit Tansel. 2006. "Economic Performance and Political Outcomes: An Analysis of the Turkish Parliamentary and Local Election Results Between 1950 and 2004". Public Choice, Vol.129, pp -77-105.

Akarca, Ali and Aysit Tansel. 2007. "Social and Economic Determinants of Turkish Voter Choice in the 1995 Parliamentary Election". Electoral Studies, Vol. 26, pp-633-647.

Andreoni, J. (1989). Giving with impure altruism: Applications to charity and Ricardian equivalence. Journal of political Economy, 97(6), 1447-1458.

Aran, M. A., Munoz Boudet, A. M. and Aktakke, N. (2016). Can regulations make it more difficult to serve the poor? The case of childcare services in Istanbul, Turkey. Journal of Human Development and Capabilities, 17(4), 558-582.

Arnold, David.2013. "The Effect of Children on Voter Turnout". (Undergraduate Thesis), Retrieved from MLA University of California, Berkeley Database.

Atasoy, B. S. (2017). Testing the environmental Kuznets curve hypothesis across the US: Evidence from panel mean group estimators. Renewable and Sustainable Energy Reviews, 77, 731-747.

Başlevent, C., Kirmanoğlu, H. and Şenatalar, B. (2005). Empirical investigation of party preferences and economic voting in Turkey. European Journal of Political Research, 44(4), 547-562.

Blais, A. (2000). To vote or not to vote?: The merits and limits of rational choice theory. University of Pittsburgh Pre.

Brady, H. E., Verba, S. and Schlozman, K. L. (1995). Beyond SES: A resource model of political participation. American political science review, 89(2), 271-294.

Bratton, K. A. and Ray, L. P. (2002). Descriptive representation, policy outcomes, and municipal day-care coverage in Norway. American Journal of Political Science, 428-437.

Buğra, A. and Yakut-Cakar, B. (2010). Structural change, the social policy environment and female employment in Turkey. Development and change, 41(3), 517-538.

Burns, N., Schlozman, K. L. and Verba, S. (2001). The private roots of public action. Harvard University Press.

Cancela, J. and Geys, B. (2016). Explaining voter turnout: A meta-analysis of national and subnational elections. Electoral Studies, 42, 264-275. 
Çarkoğlu, Ali. 1997. "Macroeconomic Determinants of Electoral Support for Incumbents in Turkey: 1950-1995”. New Perspectives on Turkey Vol. 17, pp-:75-96

Childs, S. (2004). A feminised style of politics? Women MPs in the House of Commons. The British Journal of Politics and International Relations, 6(1), 3-19.

Dale, A. and Strauss, A. (2009). Don't forget to vote: text message reminders as a mobilization tool. American Journal of Political Science, 53(4), 787-804.

Dedeoğlu, S. (2010). Visible hands-invisible women: Garment production in Turkey. Feminist Economics, 16(4), 1-32.

Degan, A. and Merlo, A. (2004). Do citizens vote sincerely (if they vote at all)? theory and evidence from us national elections.

Downs, A. (1957). An economic theory of democracy. New York: Harper \& Row

Ferejohn, J. A. and Fiorina, M. P. (1974). The paradox of not voting: A decision theoretic analysis. American political science review, 68(2), 525-536.

Fowler, J. H. (2006). Altruism and turnout. The Journal of Politics, 68(3), 674-683.

Fowler, J. H. and Kam, C. D. (2007). Beyond the self: Social identity, altruism, and political participation. The Journal of politics, 69(3), 813-827.

Fowler, J. H. and Dawes, C. T. (2008). Two genes predict voter turnout. The Journal of Politics, 70(3), 579-594.

Fowler, J. H., Baker, L. A. and Dawes, C. T. (2008). Genetic variation in political participation. American Political Science Review, 102(2), 233-248.

Franklin, Mark N. 1996. "Electoral Participation." In Comparing Democracies: Elections and Voting in Global Perspective, ed. Lau- rence LeDuc, Richard G. Niemi, and Pippa Norris. Thousand Oaks, CA: Sage.

Gallego, A. (2009). Where else does turnout decline come from? Education, age, generation and period effects in three European countries. Scandinavian Political Studies, 32(1), 23-44.

Gelman, A., King, G. and Boscardin, W. J. (1998). Estimating the probability of events that have never occurred: when is your vote decisive?. Journal of the American Statistical Association, 93(441), 1-9.

Gerber, A. S. and Rogers, T. (2009). Descriptive social norms and motivation to vote: Everybody's voting and so should you. The Journal of Politics, 71(1), 178-191.

Gerber, A. S., Green, D. P. and Larimer, C. W. (2008). Social pressure and voter turnout: Evidence from a large-scale field experiment. American political Science review, 102(1), 3348. 
Gerber, A. S., Huber, G. A., Doherty, D., Dowling, C. M. and Hill, S. J. (2013). Do perceptions of ballot secrecy influence turnout? Results from a field experiment. American Journal of Political Science, 57(3), 537-551.

Gimpel, J. G. and Schuknecht, J. E. (2003). Political participation and the accessibility of the ballot box. Political Geography, 22(5), 471-488.

Gimpel, J. G., Kaufmann, K. M. and Pearson-Merkowitz, S. (2007). Battleground states versus blackout states: The behavioral implications of modern presidential campaigns. The Journal of Politics, 69(3), 786-797.

Granberg, D. and Holmberg, S. (1992). The Hawthorne effect in election studies: The impact of survey participation on voting. British Journal of Political Science, 22(2), 240-247.

Grilli, L. and Rampichini, C. (2014). Ordered logit model. Encyclopedia of quality of life and well-being research, 4510-4513.

Güvercin, D. (2019). Women in Politics and Child Labor: An Instrumental Variable Approach European Journal of Development Research https://doi.org/10.1057/s41287019-00243-1

Güvercin, D.2017. "How Terrorist Attacks Affect Voter Turnout Rate in Turkey: Regional Analysis?”.Sosyal Bilimler Araştırma Dergisi, Vol.6, pp-122-136.

Harsanyi, J. C. (1977). Morality and the theory of rational behavior. Social research, 623-656.

İlkkaracan, İ. (2012). Why so few women in the labor market in Turkey?. Feminist Economics, 18(1), 1-37.

İlkkaracan, İ. (2012). Why so few women in the labor market in Turkey?. Feminist Economics, 18(1), 1-37.

Inglehart, R., Norris, P. and Ronald, I. (2003). Rising tide: Gender equality and cultural change around the world. Cambridge University Press.

Iversen, T. and Rosenbluth, F. (2008). Work and power: The connection between female labor force participation and female political representation. Annual Review of Political Science, 11, 479-495.

Jackman, R. W. (1987). Political institutions and voter turnout in the industrial democracies. American Political Science Review, 81(2), 405-423.

$\mathrm{J}$

ankowski, R. (2007). Altruism and the decision to vote: Explaining and testing high voter turnout. Rationality and Society, 19(1), 5-34.

Kittilson, M. C. and Schwindt-Bayer, L. A. (2012). The gendered effects of electoral institutions: Political engagement and participation. Oxford University Press. 
Kostelka, F. and Blais, A. (2018). The chicken and egg question: satisfaction with democracy and voter turnout. PS: Political Science \& Politics, 51(2), 370-376.

Lijphart, A. (1997). Unequal participation: Democracy's unresolved dilemma presidential address, American Political Science Association, 1996. American political science review, 91(1), 1-14.

Lijphart, A. (2012). Patterns of democracy: Government forms and performance in thirty-six countries. Yale University Press.

Morton, R. B. (1987). A group majority-voting model of public good provision. Social Choice and Welfare, 4(2), 117-131.

Mulligan, C. B. and Hunter, C. G. (2003). The empirical frequency of a pivotal vote. Public Choice, 116(1-2), 31-54.

Nickerson, D. W. (2006), "Volunteer Phone Calls Can Increase Turnout: Evi- dence From Eight Field Experiments," American Politics Research, 34, 271

Nickerson, D. W. and Rogers, T. (2010). Do you have a voting plan? Implementation intentions, voter turnout, and organic plan making. Psychological Science, 21(2), 194-199.

Norris, P. (2003). Will new technology boost turnout? Evaluating experiments in e-voting v. all-postal voting facilities in UK local elections.

Pacek, A. and Radcliff, B. (1995). The political economy of competitive elections in the developing world. American Journal of Political Science, 745-759.

Plutzer, Eric .2002. "Becoming a Habitual Voter: Inertia, Resources, and Growth in Young Adulthood”. American Political Science Review, Vol.96, pp- 41-56.

Putnam, R. (1993). The prosperous community: social capital and public life. The american prospect, 13(Spring), Vol. 4

Riker, W. H. and Ordeshook, P. C. (1968). A Theory of the Calculus of Voting. American political science review, 62(1), 25-42.

Sapiro, V. (1981). Research frontier essay: When are interests interesting? The problem of political representation of women. American Political Science Review, 75(3), 701-716

Schuessler, A. A. (2000). A logic of expressive choice. Princeton University Press.

Smets, K. and Van Ham, C. (2013). The embarrassment of riches? A meta-analysis of individual-level research on voter turnout. Electoral studies, 32(2), 344-359.

Stoker, L. and Jennings, M. K. (1995). Life-cycle transitions and political participation: The case of marriage. American political science review, 89(2), 421-433.

Tenn, S. (2007). The effect of education on voter turnout. Political Analysis, 15(4), 446-464. 
Thananithichot, S. (2012). Political engagement and participation of Thai citizens: the ruralurban disparity. Contemporary Politics, 18(1), 87-108.

Uhlaner, C. J. (1989). "Relational goods" and participation: Incorporating sociability into a theory of rational action. Public choice, 62(3), 253-285.

Wolfinger, N. H. and Wolfinger, R. E. (2008). Family structure and voter turnout. Social forces, 86(4), 1513-1528.

Wolfinger, R. E. and Rosenstone, S. J. (1980). Who votes? (Vol. 22). Yale University Press.

Zuckerman, A. S., Dasovic, J. and Fitzgerald, J. (2007). Partisan families: The social logic of bounded partisanship in Germany and Britain. Cambridge University Press. 